\title{
Employee benefits and discipline in private universities in Uganda
}

\author{
Emurugat Immaculate Azabo*, Sofia Sol Gaite and Yakubu Ibrahim Wunti
}

\author{
College of Education, open and distance learning, Kampala International University, Uganda. \\ *Corresponding author. Email: macuemu@gmail.com. Tel: +256 772319549.
}

Copyright @ 2017 Azabo et al. This article remains permanently open access under the terms of the Creative Commons Attribution License 4.0, which permits unrestricted use, distribution, and reproduction in any medium, provided the original work is properly cited.

Received 9th April, 2017; Accepted 1st June, 2017

\begin{abstract}
Organizations are operating in a highly competitive environment and to remain relevant they have to be able to respond quickly to ever changing customer demands. Employee benefits is one of the ways used by organizations for attracting and retaining suitable employees as well as facilitating them to improve their performance and thus ensure quality service. This study endeavours to analyze the relationship between employee benefits and discipline in private universities in Uganda. It involved 385 respondents from seven private chartered and accredited universities. Data was collected using a self-administered questionnaire whose validity and reliability was confirmed through Factor Analysis and Cronbach Alpha Test. Descriptive analysis involved the use of means (averages), while Pearson Linear Correlation Coefficient was used to test the hypothesis. The results revealed that employee benefit was a positive significant determinant of discipline of employees. In conclusion employee benefit was an important element in that it influenced the discipline of employees in private universities. It was recommended that managers of organizations such as private universities should put emphasis on employee benefit which will influence the discipline of their employees and thus their retention.
\end{abstract}

Key words: Chartered and accredited, descriptive analysis, reliability, self-administered questionnaire, validity.

\section{INTRODUCTION}

Employee benefits is one of the reward management strategies used by Human Resource Managers for attracting and retainingsuitable employees as well as facilitating them to improve their performance, ensure quality service and to comply with employment legislation and regulation. Since organizations are operating in a highly competitive environment to remain relevant, they have to be able to respond quickly to ever changing customer demands. As a result of these pressures, Human Resource Managers seek to design structures that facilitate the organizations strategic goals and the goals of individual employees. In addition to remuneration accruing to employees on the basis of performance, employees may be given benefits aimed at preventing dissatisfaction and making their work related lives materially, psychologically and socially worthwhile which is conducive to the improvement of employee performance. Employee benefits which are also called fringe benefits are advantages or rewards for employment in addition to remuneration or payment of wages or salaries (Tibamwenda, 2010).

Employee benefits include paid annual leave, study leave, medical services and sick leave with pay, provision of housing, pension arrangements, subsidized meals, provision of transport facilities and loans and salary advance. A paid annual leave is intended to enable an employee to rest. In most organisations, paid annual leaves are granted for about one month annually. It is called paid annual leave because an employee is paid some amount of money called leave allowance in addition to his normal salary while he is on leave (Maicibi, 2007). Employee benefits in any organisation should have guidelines which are based on the implementation and management of the benefits. Maicibi (2007) opines that every organisation should be able to stipulate the mode of benefit, state who qualifies for the benefit, state the mode of calculating the benefits; it states the type of pay benefits, mode of administering the benefits and the 
period of paying the benefits. In organizations, discipline is a procedure that correct or punishes an employee because a rule or procedure has been violated (Dessler, 1996). Therefore, within an organization, discipline must be viewed as a condition whereby employees know what is expected of them in terms of organization's rules standards and policies and what the consequences are of infractions (Rue and Byars, 1996). The aim of this paper is to report on the survey done on the analysis of employee benefits in chartered and accredited private universities in Uganda in relation to their discipline.

Research question: What is the relationship between employee benefits and discipline of employees in private universities in Uganda?

The second hypothesis of the study stated that:

H1: There is a relationship between employee benefits and discipline of employees in private Universities in Uganda.

\section{Related literature}

Employee benefits in any organisation should have guidelines which are based on the implementation and management of the benefits. Employee benefits can be given by comparing the relative values of different jobs in the organisation. This can be done by establishing a pay structure that is operational in the organisation (Tibamwenda, 2010).

Chandra (2009) in his study on Human Resource Management in Wadia Institute of Geology Himalaya (WIGH) found out that WIHG provides many employee benefit schemes such as contributory provident fund, gratuity group insurance schemes, subsidized accommodation, education and health care facilities, accident insurance and social security measures. The goal of job evaluation is to achieve internal equity by determining a hierarchy of jobs that is based on the relative contribution of each job to the organisation. This hierarchy is then used to allocate rates of employee benefits to jobs. If job evaluation is put into consideration employees may feel obliged to be disciplined while carrying out their duties. The importance of job evaluation to managers has increased because of the currency of equal pay legislation, which requires, that gender-neutral and personality neutral job evaluation schemes are adopted and used to determine and compare the value of jobs within an organisation in order to value the standard employee benefits.

Armstrong (2010) argued that the basic principle in giving employee benefits is giving jobs that require greater qualifications, more responsibilities, and more complex job duties a higher pay than jobs with lesser requirements. The basic procedure is to compare the jobs in relation to one another (for example, in terms of required effort, responsibility, and skills). If employee's jobs are not compared to determine the worth of their jobs, then some employees may end up being indisciplined at work because they may feel that they may be working more and being paid less.

Discipline is an inevitable correlate of organisations and is one of the major functions of performing managers (Itang, 2015; Maicibi, 2007; Pacitti, 2011). Discipline can be defined as a state of self-control and orderly conduct of an individual in accordance with the acceptable standard mode of behaviour. It can also be referred to as the person's ability to control his own behaviour so that he/she does what is expected of him/her. It further refers to the practice of training people to obey rules, regulations and orders and punishing them if they do not. When an organisation is not satisfied with the behaviour of an employee, it can take disciplinary action against $\mathrm{him} / \mathrm{her}$ aimed at maintaining standards consistent with an organization's mission and strategic goals (Tibamwenda, 2010). Hersey and Blanchard et al (1993) traced the word "discipline" to have come from the word 'disciple'. Considering a disciple to be a learner, they referred to discipline as a learning process that provides an opportunity for positive growth. However, for organization, staff discipline is a condition where by employees conducts themselves in accordance with the organisation rules and standard acceptable behaviour. This definition is the same as the one by Jones, George and Hills (2000), who defined discipline as obedience, synergy, application and other outward mark of respect for superior's authority. It can be further considered as the general conduct or behaviour of people in a particular setting. So, it can be concluded that the discipline of work is an effort of the management organization of the company to implement or execute the rules or regulations that must be adhered to by all employees without exception. Tibamwenda (2010) defined organization staff discipline as a state of self-control and orderly conduct of an individual in accordance with the acceptable standard mode of behaviour. In order to flourish and survive, organizations including Universities must drive the need to concentrate on stimulating self-discipline at work Fowers (2008).

\section{METHODOLOGY}

\section{Research design}

The study employed a descriptive cross-sectional survey research design to establish the relationship between Employee benefits and discipline in chartered and accredited private universities. Descriptive survey design enabled to describe the state of affairs as they are and report the findings (Kothari, 2004). The study adopted concurrent triangulation of both quantitative and quali- 
tative approaches to data collection making it a mixed methods approach.

\section{Population and sample size}

The target population was 7,185 employees by the year 2016 from the private universities in Uganda. The population included employees of private chartered and accredited universities such as lecturers (7164), University administrators (7), Heads of Departments (7) and the Human Resource Personnel (7). The seven private universities were purposively chosen on the basis that in addition to being chartered, they are accredited implying that they have met the required standards of operating as universities. The sample size for the study was calculated based on Krejcie and Morgan (1970) formula.

\section{Data collection method and instrument}

Questionnaires and interview guide were used as data collection instruments. Self-constructed questionnaires which comprised of both structured and unstructured questions were used in the study. The questionnaire comprised of five sections. Section A was on demographic characteristics of the respondents and had 6 items on gender, age, working experience, academic qualifications, workload and length of stay in a particular university. Section B on reward management strategies specifically employee benefits which constituted one of the independent variables (IV) and had 10 items. The third section was on employee discipline and had 12 items which was the dependent variable (DV). The response modes of the questionnaire variables were rated as Strongly Agree (4), Agree (3), Disagree (2) and Strongly Disagree (1). Interviews were administered by the researcher to Heads of Departments, University Administrators and Human Resource Personnel. These respondents were interviewed because they had in depth information for the study while the research assistants gave questionnaires to the lecturers. The researcher obtained an authorization letter from the College of Education, Distance, and e-Learning (COEDL) of Kampala International University.

\section{Validity and reliability}

Validity refers to the accuracy, correctness, meaningfulness of inferences and soundness of results of conclusion, which are based on the research findings (Kothari, 2004). The researcher sought expert opinion on content and construct validity. In this study, ensuring validity of the data collection instrument involved going through the questionnaire in relation to the set objectives and making sure that it contains all the information that can enable answer these objectives. Reliability measures the degree to which a research instrument yields consistent results or data after repeated trials. To ensure reliability, the questionnaire was pre-tested on thirty employees from Islamic University in Uganda (IUIU) who were not part of the respondents. In this study a reliability co-efficient (Alpha value) of more than 0.7 was assumed to reflect the acceptable reliability. The Cronbach alpha for the two constructs were; Employee benefit $(\alpha=.743)$ and Discipline $(\alpha=.804)$. The overall Cronbach alpha was 0.761 for employee questionnaire and therefore both constructs were considered reliable and thus the instruments were adopted for the study. The objective of pre-testing was to allow for modifications of various questions in order to rephrase, clarify and clear up any shortcomings in the questionnaire.

\section{Ethical consideration}

This work was approved by the ethical steering committee of Kampala International University. The respondents' participation was voluntary and free. During the research, there was no promise of benefits for participation and the respondents were required to sign the informed consent letter. The respondents were further assured of privacy and confidentiality of the information obtained from them. The researcher has acknowledged the authors mentioned in the study by documenting in references and citing authors. The presentations of the findings have also been generalized. Permission was sought and granted by the ethical steering committees of the various universities which were included in the study.

\section{Data analysis and presentation}

Quantitative data from the proposed research was coded, processed and analyzed using computer based statistical package for social sciences (SPSS). Descriptive statistics in form of frequencies, percentages, mean were used to make comparisons of the responses. The hypothesis that there is a relationship between employee benefit and discipline in private Universities in Uganda was tested using Pearson Product Moment Correlation Coefficient. This is because the hypothesis is concerned with relationships, and it is Pearson Correlation Coefficient that is appropriate for testing such relationships.

Qualitative data that was collected during the interviews was also presented and discussed to supplement the quantitative data to bring out situations clearly for easy understanding by the readers. The qualitative data collected using interviews and the open-ended questionnaire in the semi-structured questionnaire was basically on the relevant aspect of the research and was analysed using content analysis. 


\section{RESULTS AND DISCUSSION}

\section{Demographic characteristics}

Frequency distributions were gotten for all the demographic variables. The frequencies for the number of individuals related to gender include 172 males and 137 females out of 309 respondents which constituted $55.7 \%$ males and $44.3 \%$ females respectively. The study findings showed that majority $(55.7 \%)$ of the respondents were male. This implies that there were more male lecturers working in private universities in Uganda as compared to their female counterparts. This contradicts the findings of Nguyen et al. (2003) which revealed that more women were working in private universities than men. Malik (2011) highlighted 120 Faculty members regarding their job satisfaction; he suggested that the level of job satisfaction among males was much less compared to that of female Faculty members. This has been attributed to a lower expectation on the job due to the conventional poor position of women in the labor market (Blanchflower and Oswald, 2000). However, Ibrahim et al., (2011) argued that gender has insignificant influence on job satisfaction. Similarly, Sseganga and Garrett (2005) conducted research in Uganda and found that gender has no influence on job satisfaction of university Faculty members. From the study it can be shown that males could be more satisfied in their work as compared to the females especially in the teaching profession.

It was observed that $194(62.8 \%)$ of respondents were Master holders, 76 (24.6) Bachelor holders, 36 (11.7\%) $\mathrm{PhD}$ holders and $3(1.0 \%)$ Certificate/Diploma holders as far as academic qualifications are concerned. From the responses, it can be deduced that the majority $(62.8 \%)$ of the respondents were master degree holders. This shows that majority of the staff working in private universities in Uganda are master degree holders. According to Saif et al. (2012), education level of employees is critical in defining job satisfaction in any organization. In this study, there were low numbers of PhD holders in private universities showing that maybe some employees migrate to public universities or other organizations where they are rewarded well and are more satisfied with their work. Among them, $121(39.2 \%)$ have stayed in a particular private university where they are currently teaching between 4 to 6 years, $82(26.5 \%)$ less than 3 years, $67(21.7 \%)$ between 7 to 9 years and $39(12.6 \%)$ for more than 10 years. This shows that most of the private university employees had stayed in one university for a period of 4 to 6 years, implying that most of the private university employees in Uganda leave their employment earlier. An indication that they were not satisfied with their work as stated by McEwen (2011) who noted that work engagement comes from the perceptions and evaluations of employees toward their working experience and benefits from their employers. On the working status of respondents $147 \quad(47.8 \%)$ were permanent employees, $91(29.4 \%)$ were part time employees and $71(23.0 \%)$ are working as contractual or casual employee. This shows that majority of the employees in the private universities are employed permanently, indicating that most of the private universities in Uganda recruit their employees as permanent and full time staff.

\section{Employee benefits}

Table 1 shows that out of the three hundred and nine (309) respondents, one hundred and thirty five (135) or $43.7 \%$ disagreed with the statement that their Universities provided employees with holidays, eighty seven (87) or $28.2 \%$ respondents strongly disagreed with the statement, sixty one $(61)$ or $19.7 \%$ respondents agreed with the statement while twenty six (26) or $8.4 \%$ respondents strongly agreed with the statement. The study found a mean of $1.87 \pm 1.106$ which is fair on the statement showing that a majority $(71.9 \%)$ of the private university employees in Uganda were not provided with holidays. This shows that many employees in private universities work during holidays. This is attributed to the school based programmes like in service that are run by the private universities leaving no time for employees to have holidays and could lead to burn out which can affect the employees' performance.

Similarly, ninety six (96) or $31.1 \%$ respondents disagreed with the statement that they received medical and health care services from the university, ninety one (91) or $29.4 \%$ respondents agreed, sixty seven (67) or $21.7 \%$ respondents strongly agreed while fifty five (55) or $17.8 \%$ respondents strongly disagreed. From the responses, a mean score of $1.98 \pm 1.238$ which is fair on employees' responses and this shows that majority $(51.1 \%)$ of the private universities employees were provided with medical and health care services by their employers. This shows that more private universities provide medical schemes for their employees making them committed to their work and thus influenced their work discipline.

Further, one hundred and ten (110) or $35.6 \%$ respondents strongly disagreed that employees were given free welfare services, one hundred eight (108) or $35.0 \%$ respondents disagreed and seventy four (74) or $23.9 \%$ respondents agreed while seventeen (17) or 5.5\% respondents strongly agreed with the statement. From the responses, a mean score of $1.24 \pm .980$ which is interpreted as fair shows that majority $(70.6 \%)$ of the employees in private universities in Uganda were not given free welfare services by their employers. This implies that private universities do not engage their employees in welfare services reducing employees' job satisfaction and commitment and could lead the employees to look for another job augment their income. 
Table 1. University staff responses on employee benefits. $n=(309)$.

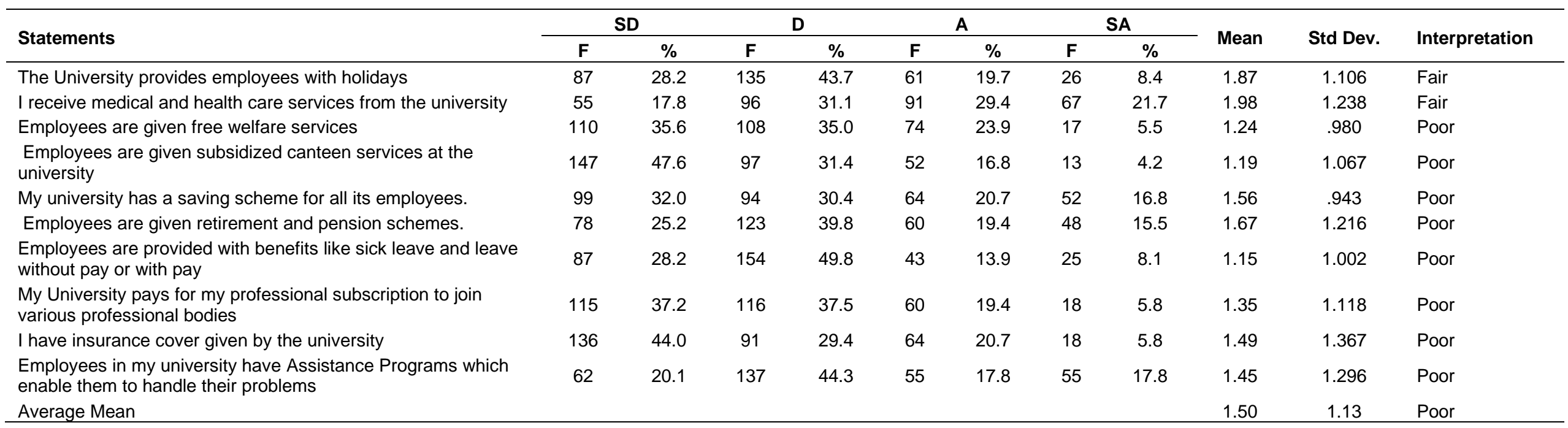

Source: Field Data, 2016.

In addition, one hundred and forty seven (147) or $47.6 \%$ respondents strongly disagreed that employees are given subsidized canteen services at the university, ninety seven (97) or $31.4 \%$ respondents disagreed and fifty two (52) or $16.8 \%$ respondents agreed while thirteen (13) or $4.2 \%$ respondents strongly agreed. From the responses, a mean score of $1.19 \pm 1.067$ was obtained which means fair. It shows that majority $(79.0 \%)$ of the university employees cited that they were not given any subsidized canteen services in their Universities.

In addition, ninety nine (99) or $32.0 \%$ respondents strongly disagreed that their universities had saving schemes for all employees, ninety four (94) or $30.4 \%$ respondents disagreed, sixty four (64) or $20.7 \%$ respondents agreed and fifty two (52) or $16.8 \%$ respondents strongly agreed. A mean score of $1.19 \pm 1.067$ was obtained which is interpreted as fair. It shows that majority (62.4\%) of the private universities' employees believed that their employers never provided them with saving schemes which can assist them in their emergency needs.

Moreover, one hundred twenty three (123) or $39.8 \%$ respondents disagreed that employees are given retirement and pension schemes, seventy eight (78) or $25.2 \%$ respondents strongly disagreed and forty three (43) or $13.9 \%$ respondents agreed while forty eight (48) or $15.5 \%$ respondents strongly agreed. A mean score of $1.67 \pm 1.216$ was obtained which means fair. It shows that majority $(65.0 \%)$ of the university employees were not given any retirement or pension schemes. This could lead to job insecurity and job dissatisfaction. The employees will try to look for other jobs where retirement schemes are offered so that they can have something to fall back to when they have retired.

Similarly, one hundred fifty and four (154) or $49.8 \%$ respondents disagreed that employees are provided with benefits like sick leave and leave without pay or with pay, eighty seven (87) or $28.2 \%$ respondents strongly disagreed and forty three (43) or $13.9 \%$ respondents agreed while twenty five (25) or $8.1 \%$ respondents strongly agreed. From the responses, a mean score of $1.15 \pm 1.002$ was obtained which is fair. It shows that majority $(78.0 \%)$ of the private university employees were not provided with benefits like sick leave or leave with/without pay. This shows that most private universities do not give sick leaves or other kinds of leaves to their employees. It means that an employee will have to take of themselves to avoid being sick. This could lead to demotivation and poor performance of the employees. 
Furthermore, one hundred sixteen (116) or $37.5 \%$ respondents disagreed that their universities pay for their professional subscription to join various professional bodies, one hundred and fifteen (115) or $37.2 \%$ respondents strongly disagreed and sixty (60) or $19.4 \%$ respondents agreed while eighteen (18) or $5.8 \%$ respondents strongly agreed. From the responses, a mean of $1.35 \pm 1.118$ was obtained which is fair. It shows that majority $(74.7 \%)$ of the private universities never paid for their employees' professional subscription to professional bodies. Payment of professional subscription fee by employers is a way of offering some fringe benefits to the employees which helps them in their professional growth. Publications and membership to professional organisation will also boost the morale of the employees which can enhance their performance in their work.

Similarly, one hundred thirty six (136) or $44.0 \%$ respondents strongly disagreed that they had insurance covers given by the universities, ninety one (91) or $29.4 \%$ respondents disagreed and sixty four (64) or $20.7 \%$ respondents agreed while eighteen (18) or $5.8 \%$ respondents strongly agreed. From the responses, a mean of $1.49 \pm 1.367$ was obtained which is fair. It shows that majority $(73.4 \%)$ of the employees working in private universities were not given insurance covers by their employers. This means that private universities are not giving any insurance for their employees not even a group health insurance. It is the employee himself or herself who will get the insurance cover for themselves. In some universities their benefit is optional.

In addition, one hundred thirty seven (137) or $44.3 \%$ respondents disagreed that employees in their university had Assistance Programs which enabled them to handle their problems, sixty two (62) or $20.1 \%$ respondents strongly disagreed and fifty five (55) or $17.8 \%$ respondents strongly agreed while another fifty five (55) or $17.8 \%$ respondents agreed. From the responses, a mean of $1.45 \pm 1.296$ was obtained which means fair Majority (64.4\%) of the private universities staffs in Uganda do not have assistance programs which enable them to handle their problems. This can affect their work performance because if someone has a problem then he or she cannot concentrate on his or her work until the problem is resolved.

On average a mean score of $1.50 \pm 1.13$ was obtained which is fair regarding employee benefits and discipline. This implies that private university in Uganda poorly regard employee benefits and therefore the university management need to re-look into better ways of providing employee benefits to ensure that their employees are well motivated to do their work to avoid indiscipline.

On interviewing the human resource personnel and university administrators on employee benefits and discipline one of the human resource personnel indicated that:

"We have canteens but they are used by both lecturers and students as well. Lecturers have no special welfare package apart from medical treatment when you fall sick while at campus. There are no insurance covers that are offered here. We work throughout the year because students are admitted thrice in a year therefore we don't have any holidays."

One administrator further added that:

"When you go for a holiday you can find someone has already replaced you at work whether it is sick leave or maternity leave, the case is the same.

One Head of Department mentioned that:

"..it is usually hard even to go for Sabbatical years and yet it is our right. We have to be on the ground always".

The researcher thus concluded that private university employees are rarely given any employee benefits by their employers thus leading to the indiscipline in the university.

\section{Employee discipline}

The dependent variable was divided into aspects namely; attend to their duties regularly at the university, mark student's course works in time, follow rules and regulations, work in other universities apart from the one I am teaching, not punctual and punished after some time, accomplish all tasks and assignments in time, accountable for their actions, responsibility of taking care of goods and property, I am satisfied with my job and thus very honest in carrying out my duties, salary I earn is enough for me to remain working and my university has an employee handbook about the rules and regulations of my institution. The items were scaled using the four point Likert scale ranging from a minimum of 1 for the worst case scenario (Strongly disagree) to a maximum of 4 , which is the best case scenario (strongly agree). Table 1 illustrates all the elements of discipline as listed above. From the Table 1, it was observed that most of respondents agreed with the statements in the list since their means were above 3 on the Likert scale apart from two issues on "I am satisfied with my job and thus very honest in carrying out my duties and salary I earn is enough for me to remain working which had a mean less than 3". However, an overall mean of about 3 , which on the scale used corresponded to agree and hence a good overall rating of discipline in private universities.

Table 2 shows statements on employee discipline. In item one with the statement that "employees attend to their duties regularly at the university", out of three hundred and nine (309) respondents, one hundred and seventy six (176) or $57.0 \%$ respondents agreed, one hundred and eight (108) or $35.0 \%$ respondents strongly agreed and twenty two (22) or $7.1 \%$ respondents 
Table 2. Frequency, Percentages and Means of Employee Discipline $(n=309)$.

\begin{tabular}{|c|c|c|c|c|c|c|c|c|c|c|c|}
\hline \multirow{2}{*}{ Statement } & \multicolumn{2}{|c|}{ SD } & \multicolumn{2}{|c|}{ D } & \multicolumn{2}{|c|}{ A } & \multicolumn{2}{|c|}{ SA } & \multirow{2}{*}{$\begin{array}{c}\text { Mea } \\
n\end{array}$} & \multirow{2}{*}{$\begin{array}{l}\text { Std } \\
\text { Dev. }\end{array}$} & \multirow{2}{*}{ Remarks } \\
\hline & $\mathrm{F}$ & $\%$ & $\mathrm{~F}$ & $\%$ & $\mathrm{~F}$ & $\%$ & $\mathrm{~F}$ & $\%$ & & & \\
\hline Employees attend to their duties regularly at the university & 3 & 1.0 & 22 & 7.1 & 176 & 57.0 & 108 & 35.0 & 3.42 & .876 & Very Good \\
\hline Employees mark student's course works in time in my university & 3 & 1.0 & 37 & 12.0 & 182 & 58.9 & 87 & 28.2 & 3.46 & .912 & Very Good \\
\hline Employee's always follow rules and regulations of the university & 5 & 1.6 & 46 & 14.9 & 189 & 61.2 & 69 & 22.3 & 3.51 & .867 & Very Good \\
\hline Employees work in other universities apart from the one I am teaching in. & 24 & 7.8 & 85 & 27.5 & 137 & 44.3 & 63 & 20.4 & 3.28 & .991 & Very Good \\
\hline $\begin{array}{l}\text { Employees who are not punctual are punished after some time in my } \\
\text { university. }\end{array}$ & 38 & 12.3 & 20 & 6.5 & 133 & 43.0 & 118 & 38.2 & 3.33 & 1.004 & Very Good \\
\hline Employees accomplish all tasks and assignments in time at the university. & 20 & 6.5 & 87 & 28.2 & 160 & 51.8 & 42 & 13.6 & 3.49 & .882 & Very Good \\
\hline Employees are accountable for their actions in the university. & 14 & 4.5 & 37 & 12.0 & 195 & 63.1 & 63 & 20.4 & 3.53 & .789 & Very Good \\
\hline $\begin{array}{l}\text { Employees have the responsibility of taking care of goods and property of } \\
\text { the university. }\end{array}$ & 11 & 3.6 & 48 & 15.5 & 165 & 53.4 & 85 & 27.5 & 3.44 & .942 & Very Good \\
\hline $\begin{array}{l}\text { I am satisfied with my job and thus very honest in carrying out my duties. } \\
\text { The salary I earn is enough for me to remain working at my university. }\end{array}$ & $\begin{array}{l}79 \\
74\end{array}$ & $\begin{array}{l}25.6 \\
23.9\end{array}$ & $\begin{array}{l}142 \\
115\end{array}$ & $\begin{array}{l}46.0 \\
37.2\end{array}$ & $\begin{array}{l}65 \\
91\end{array}$ & $\begin{array}{l}21.0 \\
29.4\end{array}$ & $\begin{array}{l}23 \\
29\end{array}$ & $\begin{array}{l}7.4 \\
9.4\end{array}$ & $\begin{array}{l}1.45 \\
1.32\end{array}$ & $\begin{array}{l}1.245 \\
1.082\end{array}$ & $\begin{array}{l}\text { Poor } \\
\text { Poor }\end{array}$ \\
\hline $\begin{array}{l}\text { My university has an Employee Handbook about the rules and regulations } \\
\text { of my institution }\end{array}$ & 42 & 13.6 & 54 & 17.5 & 109 & 35.3 & 104 & 33.7 & 3.31 & .987 & Very Good \\
\hline Average Mean & & & & & & & & & 3.05 & 962 & \\
\hline
\end{tabular}

Source: Field Data, 2016.

disagreed while three (3) or $1.0 \%$ respondents strongly disagreed. The study found a mean of $3.42 \pm 0.876$ which reflects a positive response. It shows that majority $(92.0 \%)$ of the private universities staff in Uganda reported that employees in private universities attended to their duties on regular basis. This implies that majority of the private university employees in Uganda are committed when it comes to attendance of duty thus implying that they are disciplined.

Similarly, in item 2 with the statement that 'employees mark student's course works in time in their universities', out of three hundred and nine (309) respondents, one hundred and eighty two (182) or $58.9 \%$ respondents agreed, eighty seven (87) or $28.2 \%$ respondents strongly agreed and thirty seven (37) or $(12.0 \%)$ respondents disagreed while three (3) or $1.0 \%$ respondents strongly disagreed with the statement. From the responses, a mean score of $3.46 \pm 0.912$ was obtained which is interpreted as very good. It shows that majority $(87.1 \%)$ of the respondents noted that students' work were marked in time by lecturers and this was a sign of employee discipline in the organization. Timely working on assignments given is an indication that the employees are committed and thus disciplined on their work.

Furthermore, on item 3 with the statement that 'employee's always follow rules and regulations of the university', out of three hundred and nine (309) respondents one hundred and eighty nine (189) or $61.2 \%$ respondents agreed, sixty nine (69) or $22.3 \%$ respondents strongly agreed and forty six (46) or (14.9\%) respondents disagreed while five (5) or $1.6 \%$ respondents strongly disagreed. From the responses, a mean of $3.51 \pm 0.867$ was obtained which meant very good. It emerged from the responses that majority $(83.5 \%)$ of the employees in private universities adhered to set rules and regulations within the university. This shows that employees are obedient and adhere to rules and regulations which govern their work and this is a sign of employee work discipline in any organization.

In addition, on item 4 with the statement that 'employees work in other universities apart from the one they were teaching in', out of three hundred and nine (309) respondents one hundred thirty seven (137) or $44.3 \%$ respondents agreed, eighty five (85) or $27.5 \%$ respondents disagreed and sixty three (63) or $20.4 \%$ respondents strongly agreed while twenty four (24) or $7.8 \%$ respondents strongly disagreed. From the responses, a mean score of $3.28 \pm 0.991$ was obtained which implies very good. It shows that majority $(64.7 \%)$ of the employees in private universities reported that their colleagues are working as part-timers in other universities. This shows that the remuneration packages being offered by private universities are not adequate to cater for the needs of its employees and therefore they (employees) work as part-timers in other universities with an aim of increasing their income. This implies that since most employees in private universities have part time jobs in other 
Table 3. Relationship between employee benefits and discipline.

\begin{tabular}{lccl}
\hline Variables correlated & $\begin{array}{c}\text { Computed r- } \\
\text { value }\end{array}$ & $\begin{array}{c}\text { P- value Sig. } \\
\text { (2tailed) }\end{array}$ & $\begin{array}{l}\text { Interpretation of } \\
\text { correlation }\end{array}$ \\
\hline Employee Benefits and Discipline & 0.590 & 0.000 & $\begin{array}{l}\text { Significant } \\
\text { relationship }\end{array}$ \\
\hline
\end{tabular}

${ }^{* *}$ Correlation is significant at the 0.01 level (2-tailed).

universities there could be a conflict of interest and the employee cannot be effective in his or her work hence it causes problems especially in the university where he or he/she is redundant and ineffective.

Furthermore on item 5 with the statement that 'employees who are not punctual were punished after some time in their universities', out of three hundred and nine (309) respondents, one hundred and thirty three (133) or $43.0 \%$ respondents agreed, one hundred and eighteen $(118)$ or $38.2 \%$ respondents strongly agreed, thirty eight (38) or $12.3 \%$ respondents strongly disagreed.

Pearson Linear Correlation Coefficient was used to examine the correlation between the independent variable (employee benefit) and the dependent variable (discipline). Pearson Linear Correlation Coefficient is a suitable method in investigating the relationship between a dependent variable and an independent variable having a purpose to explain a dependent value, described by using known value of independent variable. An influencing factor like employee benefit as independent variable is incorporated in the theoretical model; Factor (employee benefit) will be used for the examination of association between discipline as dependent variable and independent variable (employee benefit).

Pearson Linear Correlation Coefficient was used to test the hypothesis and the results are presented in Table 3. It shows that there was a significant positive correlation between employee benefits and employee discipline $(r=$ $0.590 ; p=0.000)$. Therefore, the hypothesis which stated that there is a relationship between employee benefits and discipline of employees in private Universities in Uganda is accepted because of the significance value of 0.000 . This implies that employee benefits influence the discipline of employees in the private universities. This means that private universities should ensure that they will give benefits to their employees so that they are motivated and can perform their work well to avoid indiscipline.

\section{Conclusions}

The study concluded that there was a positive significant relationship between employee benefit and discipline in private universities in Uganda. This is in an agreement with what Reilly and Brown (2008) and Brown and Reilly (2013) said that employee benefits are motivators which encourage employee commitment and thus productivity and behaviour. Although, from the responses of the University employees from the average obtained in the descriptive study on the likert scale show that the relationship is fair. This implies that private university in Uganda poorly regard employee benefits and therefore the university management need to re-look into better ways of providing employee benefits to ensure that their employees are well motivated to do their work to avoid indiscipline.

\section{Recommendation}

Employee benefits have been known to have a positive effect on employee discipline and hence performance. However, Maicibi (2007) opined that every organization should be able to stipulate the mode of benefit, state who qualifies for the benefit, state the mode of calculating the benefits; it states the type of pay benefits, mode of administering the benefits and the period of paying the benefits. In organizations, discipline is a procedure that correct or punishes an employee because a rule or procedure. Further research can be conducted by including more private universities and broadening sample size. In this research only one influencing factor like employee benefit was used.

\section{CONFLICT OF INTEREST}

The authors declare that they have no conflict of interest.

\section{REFERENCE}

Armstrong, M. (2010). Armstrong's Essential Human Resource Management Practice. 1st ed. London: Kogan Page. Practice (2nd edn) - Bath Press Avon.

Blanchflower, D., \& Oswald, A. (2000). The rising well-being of the young, in Youth Employment and Joblessness in Advanced Countries, edited by Blanchflower, D., \& Freeman R, Chicago: The University of Chicago Press.Pp. 289-328.

Brown, D., \& Reilly, P. (2013). Reward and Engagement: The New Realities. Compensation and Benefits Review, 45(3), 145-157.

Chandra, G. (2009). Master's Thesis in Human Resource Management in WIGH.Faculty of Economics, University of LJUBLJANA.

Dessler, G. (1996). Human Resource Management, 7th ed, (England wood Cliffs, NJ: Prentice Hall, p. 174. 
Fowers, B. J. (2008). From Continence to Virtue: Recovering Goodness, Character Unity, and Character Types for Positive Psychology. Theory \& Psychology, 18(5), 629-653.

Hersey, P., \& Blanchard, K. H. (1993). Management of Organizational Behaviour $\left(6^{\text {th }}\right.$ ed.) Englewood Cliff, N. J. Prentice Hall, p. 269.

Ibrahim. M., Abdulazim, G., Elkhouly, S., \& Mohsen, G. (2011). Impact of emotional intelligence and gender on job satisfaction among Egyptian Government Sector employees. Current Research Journal of Social Sciences, 3(1), 22- 27.

Itang, I. (2015). Work Discipline and Work Competence with Quality of Service in the Office of Religious Affairs (KUA) District of Mount Kencana Lebak Regency of Banten. Journal of Management and Sustainability, 5(3), 132.

Jones, G. R., George, J. M., \& Hill, C. W. L. (2000). Contemporary Management, $\left(2^{\text {nd }}\right)$ Irwin: McGraw Hill Ltd. Pp. 613-615.

Kothari, C. R. (2004). Research Methodology: Methods and Techniques. Second edition, age International publishers, Pp. 2-3.

Krejcie, R. V., \& Morgan, D. W. (1970). Determining sample size for research activities" (Educational \& Psychological measurement, 30, 607-610.

Malik, N. (2011). Study of Job satisfaction factors of faculty members at University of Baluchestan. International Journal of Academic Research, 3(1), 267-272.

Maicibi, A. (2007). Human Resource Management Success, Makerere University Printery, Kampala, Uganda. Pp. 181222.
McEwen, D. (2011). Employee engagement: A Systemic approach to high employee engagement. Available at http://www.cgnglobal.com/sites/default/files/Employee_Engag ement_CGN\%20Global.pdf.

Nguyen, A., Taylor, J., \& Bradley, S. (2003). Relative pay and job satisfaction: some new evidence. Munich Personal RePec Archive. Development and Policies Research Centre.1382, 1-24.

Pacitti, A. (2011). Efficiency Wages, Unemployment, and Labor Discipline. Journal of Business \& Economics Research, 9.3, 1-10.

Reilly P. \& Brown, D. (2008). Employee engagement: What is the relationship with reward management? WorldatWork Journal, 17(4), 37-49.

Rue, L. W., \& Byars, L.L., (1996). Supervision: key link to productivity ( $5^{\text {th }}$ ed.). Chicago: Irwin. Pp. 276-278.

Saif-Ud-Din, K., Nawaz, A., \& Jan, F. A. (2012). Impact of Demographic Diversities on the Job Satisfaction and its Consequences: Case of Academicians in Higher Learning Institutions of Pakistan. Global Journal of Management and Business Research, 12(19), 35-43.

Ssesanga, K., \& Garret, R. (2005). Job satisfaction of University Academics: Perspectives from Uganda Higher Education. 50 (1), 33-56.

Tibamwenda, J. (2010). Modern Management Theories and Practices- A productivity and profitability Approach, Macmillan Uganda Limited, Uganda. Pp. 453-454. 